\title{
Nagy Sándor
}

\section{A tudásintenzív üzleti szolgáltatások innovációs jellemzői}

A cikk a szolgáltatások innovációs megközelítéséből kiindulva lehatárolja a tudásintenzív üzleti szolgáltatásokat, összefoglalja azok innovációs jellemzőit. Megállapítja, hogy az egyes szolgáltatási tevékenységeknélmás szektorokhoz viszonyítva hiányoznakazösztönzéshez szükséges intézményiés egyéb formális támogató rendszerek, amelyek nemcsak tudásközpontokként szolgálhatnának a vállalkozások számára, hanem hozzájárulhatnának az innovációk védelméhez és terjedéséhez is. A szellemi tulajdonnak a szolgáltatások körében hiányzó hatékony védelme (a termelö szektorral ellentétben) nagy kockázatot jelent, ami gátolja az optimális tudástranszfert, és pazarló, duplikált innovációs erőfeszítéseket okoz.

Journal of Economic Literature (JEL) kódok: O31, O32, L84

Kulcsszavak: szolgáltatás innováció, tudásintenzív üzleti szolgáltatások, KIBS

$\mathrm{Az}$ innováció mint értékteremtő tevékenység a szakirodalomban elsőként Joseph Schumpeter írásaiban jelent meg, aki azzal érvelt, hogy az innováció nem csupán az ötlet vagy a találmány szintjén értelmezhető, hanem alkalmazása révén eredeztethető a növekvő termelékenység. Az innováció így elválaszthatatlan az általa gerjesztett gazdasági értéktől. Ezen értelmezés igen hasznosnak bizonyult a tudományos kutatásokhoz, hiszen általa kvantitatívan mérhetővé vált az innováció, jóllehet a módszertanok még jelenleg sem teljesen egységesek.

Az innováció átfogó kutatása hagyományosan a termelő ágazatok elemzésén keresztül történt. A szolgáltatások innovációs szerepét a kutatók alulreprezentáltnak tekintették mind a statisztikai, mind pedig a közgazdaságtani vizsgálódásokban. A felismerés ugyanakkor, hogy a szolgáltatások, különösen a tudásintenzív üzleti szolgáltatások (Knowledge Intensive Business Services - KIBS) nagyban hozzájárulnak a gazdasági növekedéshez, megváltoztatta ezt a szemléletet, és a kutatók ma már a szolgáltatásokat saját innovációval rendelkező ágazatnak tekintik. ${ }^{1}$ A szolgáltatások marginális innovációs értelmezését az is okozhatta, hogy az iparág vállalkozásai közt relatíve fölülreprezentáltak a kisméretü szervezetek. Ebből fakadóan gyakran hiányoznak a belső innovációhoz szükséges

Nagy Sándor PhD-hallgató a Miskolci Egyetem Gazdálkodástani Intézetében. E-mail: sandor.nagy.hu@gmail.com.

1 A tudományos kutatások mellett az üzleti élet és az állami szabályozás is változó szemlélettel tekint a szolgáltatások innovációs szerepére. Ennek kiváló dokumentációs példája a Magyarországon is széles körben használt OECD-kiadványok közül az Oslo kézikönyv, illetve a Frascati kézikönyv, amelyek az innováció szélesebb, a szolgáltatások esetében is alkalmazható értelmezését tartalmazzák. 
források, s a szolgáltató vállalkozások zömmel inkább a külső innovációra és technológiára támaszkodhatnak. Emiatt lehet jelentős szerepe továbbá az innovációs költségek és infrastruktúra vállalkozások közötti megosztásának is, ami jellemzően a klaszterekben és egyéb hálózatos együttműködésekben valósul meg. A következőkben - a szolgáltatások innovációs tevékenységének tudományos megközelítésére alapozva - a tudásintenzív üzleti szolgáltatások jellemző innovációs tulajdonságait mutatom be.

\section{A szolgáltatások innovációs megközelítése}

Egészen az utóbbi három évtizedig a szolgáltatások közgazdaságtani megítélése Adam Smith nézőpontján alapult, aki a szolgáltatásokat - abból kiindulva, hogy azok a munkaerőnek viszonylag kis hányadát érintik - nem tekintette jelentős tényezőnek a gazdasági növekedésben. A tercierizálódás ugyanakkor felkeltette a kutatók érdeklödését, amelynek részeként a szolgáltatások innovációs jellemzői is a fókuszba kerültek, annál is inkább, mert az utóbbi évtizedekben a szolgáltató szektor output mennyisége és foglalkoztatottsági aránya a legmagasabb a fejlett gazdaságokban. Ezen országokban (köztük az Európai Unió tagállamaiban is) a foglalkoztatottság növekedési ütemét tekintve a szolgáltatások dominanciája még szembetünőbb, míg a termelésben egyre zsugorodik. A korai kutatók leginkább arra keresték a választ, hogy a szolgáltatások innovációs folyamatai vajon különböznek-e, és ha igen, akkor milyen módon, a termékek innovációitól. A 80-as évektől a kutatások (időrendi és logikai sorrendben) az úgynevezett asszimiláció - demarkáció szintézis nézőpontokat követve alakultak.

Az asszimilációs (vagy technológiai) megközelítés szerint a szolgáltatásokat alapvetően a termeléssel azonosan kell kezelni. Ebből kifolyólag az eredetileg a termelő tevékenységre kidolgozott elméletek, valamint az empirikus módszerek és mutatószámok ugyanúgy alkalmazhatóak az esetükben is, következésképpen a szolgáltatás innováció kutatása az általános, a termék innovációra kidolgozott elméleti kutatásokhoz hasonlóan történhet. Ez a módszertani vonal Gallouj és Savona szerint Pavitt és szerzőtársai kutatási eljárásához vezethető vissza (Gallouj-Savona 2009). Ugyanígy, Barras munkája is jelentősen hozzájárult a tématerület elméleti megalapozásához, aki a szolgáltatások innovációját beszállítói indíttatásúnak tartotta, ahol az innovációs folyamatok eredője a termelő szektor (Barras 1986). Jóllehet már ezen kutatások körében is megjelent a nézet, miszerint a szolgáltatások nem számítanak innovációs szempontból lemaradó szektornak, azonban még tipikusan a termelő szektorból kiinduló, az ott felmerült innovációk adoptív alkalmazóinak tekintették a szolgáltató vállalkozásokat, ahol az innováció terjedésének csatornája a szállítói lánc. Így tulajdonképpen a termelő vállalatok irányából érkező kényszerítő nyomás eredményeként alakulnak ki innovációk a szolgáltatásokban. Jóllehet Pavitt a számítástechnikai, telekommunikációs és kutatás-fejlesztési szolgáltatásokat innovátoroknak tartotta, a teljes szolgáltatói ágazatra vonatkoztatva ezeket csak kivételeknek tekintette (Pavitt és szerzőtársai 1989).

A kutatásokidőrendben következő szakaszában, jellemzően a 90-es években, a demarkációs (vagy differenciáló) nézőpont szakemberei tulajdonképpen az asszimilációs elmélet antitézisét dolgozták ki, hiszen a szolgáltatás innovációt elkülönült és specifikus tevékenységnek tekintették, ezért a szolgáltatás specifikus elméletek kifejlesztését szorgalmazták. Ezen kutatások már a szervezeti innováció fontosságát is hangsúlyozták, amelyet a termék- és 
a folyamat-innováció velejárójának tartottak. Ekkor kezdtek felfigyelni a tudásintenzív üzleti szolgáltatásoknak, illetve az információs és kommunikációs technológiának (ICT) az innovációs folyamatokban betöltött szerepére is (den Hertog 2000). Mára ezen területek a szolgáltatás innovációval kapcsolatos kutatások kulcskérdései lettek, ahol leginkább két kérdéskör foglalkoztatja a kutatókat. Egyrészt, az ügyféllel történő magas fokú interakcióra alapozva kiemelik, hogy az új igények megtalálásában és az új szolgáltatások kifejlesztésében egyaránt nagy szerepet játszik a szolgáltatást nyújtó és az azt igénybe vevő fél (koprodukciós elmélet). A szakirodalmat vizsgálva jól látható, hogy ennek a területnek a vizsgálata kiemelt szerepet kap a tudásintenzív üzleti szolgáltatások esetében. Másrészt, a kutatások kiemelik a szolgáltatás innováció konkrét ügyfélproblémákra koncentráló gyakori ad hoc jellegét, ami az innováció reprodukciós kritérium különösen erős eleme. Az innováció ugyanis feltételezi a szélesebb társadalmi körben történő elterjedést, amihez reprodukálhatónak kell lennie, máskülönben csupán az üzleti müködésben jelenlévő apró, specifikus változtatások mindennapi gyakorlatáról van szó.

A szolgáltatás innováció legújabb, szintézis (vagy integrációs) szemléletű kutatóinak célja, hogy a demarkációs tanulmányok következtetéseit a termeléssel kapcsolatos munkák eredményeibe integrálják, a neo-schumpeteri innováció elmélet egységes keretrendszerén belül. Ez magában foglalja az innovációnak a Schumpeter által tárgyalt öt formáját: a termék, a folyamat, a piaci, az input és a szervezeti innovációt. A szintézis kutatóinak érvelése szerint a hagyományos, vagyis termelésközpontú innovációs kutatások a termékés a folyamat-innováció vizsgálatát helyezték előtérbe a piaci, az input és a szervezeti innovációval szemben, míg ők maguk csak az elhanyagolt innovációs eseteket helyezik fókuszba (Gallouj-Savona 2009). A neo-schumpeteri szintetizáló megközelítésnek nem csupán az a célja, hogy egy újabb elemmel egészítse ki a kutatási területet, hanem az integrált elméletalkotás áll a törekvés középpontjában, amely mind a szolgáltatások, mind pedig a termékek esetében alkalmazható téziseket eredményezhet, és az innovációs tevékenység minden aspektusát képes lefedni. Ugyanígy célja a már létező elméletek és modellek újratesztelése és kiterjesztése.

Jelenleg a szolgáltatási szektor egészében a kutatás-fejlesztési kiadások és a laboratórium szintű kutatási projektek nem képviselnek komoly hányadot, leszámítva a nagyvállalatok innovációs folyamatait. Fontos megjegyezni, hogy a szolgáltatások kutatás-fejlesztési tevékenységének statisztikai vizsgálta nagy kihívás a kutatóknak, hiszen az ebbéli kiadások értelmezése és besorolása sokszor egyáltalán nem pontos. Ezeket csak akkor tüntetik fel a $\mathrm{K}+\mathrm{F}$ ráfordítások között, ha kézzelfogható javakhoz kapcsolódnak, vagyis a fejlesztések outputjai fizikailag is megtestesülhetnek. A szolgáltatás innováció tehát nehezen felismerhetö tevékenység a vállalkozásoknak, amit empirikus eredmények is igazolnak (Mosoniné és szerzőtársai 2004). A hagyományos gondolkodásmód viszonylag könnyebben fogadja el a müszaki jellegü haladást kutatást-fejlesztésként. A K+F helyett így sokkal szignifikánsabb szerepet kap a szolgáltatás innovációban a magasan képzett (és rugalmasan alkalmazkodni képes) munkaerő, illetve az információs és kommunikációs technológia. Hasonlóképen nevezhetjük a szolgáltatás innováció hajtóerejének magukat a vállalkozókat, illetve az úgynevezett startup vállalkozásokat. A témában fellelhető szakirodalom egészét figyelembe véve az sejthető, hogy mindennek oka nem feltétlenül a formalizált kutatásfejlesztési módszerek iránti igény hiányában keresendő, sokkal inkább arról van szó, hogy még nem tart ezen a szinten a szolgáltatások innovációja. Az elméleti és módszertani haladással párhuzamosan ez vélhetően változni fog. 
Jóllehet a szolgáltatások innovációja igen heterogén képet mutat a tudományos vizsgálatok alapján, a szakemberek kísérletet tesznek a tipologizálásukra. A korai tanulmányok ezt az innováció hajtóerőire alapozták, Pavitt taxonómiájára építve. Ennek megfelelően megkülönböztethetünk beszállítói indíttatású, ügyfél vezette, belső (szervezeten belüli), valamint más iparágat támogató szolgáltatás innovációt (den Hertog és szerzőtársai 2003). Gallouj és Savona későbbi osztályozása - szintetizáló munkájukban a szerzők az innovációt nem eredménynek, hanem folyamatnak tekintik - innováció típusok helyett különböző innovációs modelleket azonosított az egyes folyamatjellemzők dinamikája alapján (GalloujSavona 2009). Ennek megfelelően az alábbiakat azonosították:

- Radikális innováció: adott szolgáltatásjellemzők magasabb szintű kínálata, a kompetenciák és a technológia egy újabb kombinációjával.Javitó innováció: változatlan szolgáltatásjellemzők magasabb minőségü változata.Növekedési innováció: új szolgáltatásjellemző megjelenése változatlan kompetenciák és technológia mellet, ám nem radikális innovációt eredményezve.Ad hoc innováció: tipikusan a konkrét ügyféligények kiszolgálásakor jön létre, a kompetenciák és a technológia immateriális elemeinek jelentős változásával (gyakori a tudásintenzív szolgáltatások körében). Rekombinációs innováció: a szolgáltatásjellemzők egy újabb asszociációja, vagy - éppen ellenkezőleg - szétválasztása (ezen vonatkozásban a növekedési innováció a rekombinációs innováció egy speciális esete).Formalizáló innováció: egy vagy több szolgáltatásjellemző standardizálása.

$\mathrm{Az}$ innovációnak erős hatása van a vállalati termelékenységre is. A szolgáltatások és a termelés innovációs tevékenységének termelékenységi összehasonlítása szembetűnő hasonlóságot mutat (Lööf-Heshmati 2006). A korábbi kutatásokat ez esetben is az nehezítette, hogy a szolgáltatások innovációs (input és output) alapadatai ritkák a statisztikai felmérésekben. Ugyanakkor az egyes típusok esetében eltérő kapcsolatokat találhatunk: a szolgáltatások termelékenységére a termék innovációk vannak a legnagyobb hatással, a folyamat innovációk következményei pedig a szolgáltatások és a termelés esetében is további kutatásokat igényelnek még (Musolesi-Huiban 2010). Hasonlóképpen eltérőek a technológiai és nem-technológiai innovációk hatásai: a jelenlegi kutatások alapján csak az előbbiek járnak közvetlen pozitív hatással a termelékenységre, jóllehet ez azt is jelentheti, hogy a nem-technológiai innovációk nem kerültek kellően specifikusan meghatározásra, ami rontja a vizsgálati következtetéseket.

A gazdaság fejlődési trendjeit követve észrevehetjük, hogy egyre nehezebb szétválasztani a termelés és a szolgáltatások innovációs tevékenységeit, ugyanis a két szféra közötti határvonal eltünőben van, és mind a termékek, mind pedig a szolgáltatások növekvő mértékben tartalmaznak elemeket a másik szektor tevékenységéből. Vagyis egyre több termék tartalmaz szolgáltatás jellemzőket, és egyre több szolgáltatás viselkedik termékként (Szabó 2002). Úgy vélem, ez a jelenség is alátámasztja a szintézis szemléletü kutatások törekvéseit.

\section{A tudásintenzív üzleti szolgáltatások lehatárolása}

Általánosabb értelmezésben a tudásintenzív üzleti szolgáltatások megnevezés a magán- és a közszektor gazdasági szervezeteinek üzleti folyamataihoz nyújtott tudásintenzív inputokat 
jelenti. A fogalmat a szakirodalom Miles nevéhez köti, aki a KIBS szolgáltatások három fö jellemzőjét azonosította (Miles és szerzőtársai 1995):

- Igen nagymértékben a professzionális tudásra támaszkodnak.Egyaránt lehetnek az információ és a tudás elsődleges forrásai, illetve felhasználói, annak érdekében, hogy ügyfeleik termelési folyamataihoz köztes szolgáltatásokat állítsanak elö.A piaci verseny szempontjából elsődlegesen az üzleti szférában jelentős a szereplők.

Miles megfogalmazásában tehát „a KIBS szolgáltatások olyan gazdasági tevékenységeket foglalnak magukban, amelyek szándéka a tudás létrehozása, összegyüjtése és terjesztése". Hasonlóan általános definíciót vázolt fel Tovoinen is, akinél a KIBS szolgáltatások olyan „szakértői cégek, amelyek szolgáltatásokat nyújtanak más cégeknek és szervezeteknek” (Toivonen 2006). Den Hertog már pontosabb definíciót javasol, aki szerint a KIBS szolgáltatók „magánvállalkozások vagy -szervezetek, amelyek nagymértékben a professzionális tudásra, azaz egy specifikus (technikai) diszciplína vagy (technikai) funkció alapú tudásra, szakértelemre támaszkodnak annak érdekében, hogy tudásalapú köztes terméket vagy szolgáltatást nyújtsanak" (den Hertog 2000). Érdemes még megemlítenünk Bettencourték definícióját, akik szerint a KIBS fogalom „olyan vállalkozásokat takar, amelyek elsődleges hozzáadott értékű tevékenysége a tudás összegyüjtéséből, létrehozásából vagy terjesztéséből áll annakérdekében, hogy személyre szabott szolgáltatási vagy termékmegoldást fejlesszenek az ügyféligények kielégítésére" (Bettencourt és szerzőtársai 2002).

A magyar szakirodalomban megjelent tanulmányok ezen definíciók szerint vizsgálódnak, ugyanakkor fontos kiemelni, hogy - Miles kutatási irányvonalához hasonlóan - az Európai Unió szervezetei által publikált anyagok is kihangsúlyozzák az információs és kommunikációs technológia szerepét a tudásintenzív üzleti szolgáltatások fejlődésében és innovációs tevékenységében. Miles ezért a KIBS vállalkozások két csoportját javasolja elkülöníteni: egyrészt a hagyományos professzionális szolgáltatásokat (P-KIBS), amelyek az új technológia intenzív felhasználói; másrészt az újtechnológia alapú szolgáltatásokat (T-KIBS), ahol a szolgáltatások lényegét az ICT alapú eljárások adják (Miles 2005). A KIBS tevékenységek besorolásához a kutatók gyakran az EU statisztikai besorolási szabványát használják (Nomenclature des activités économiques dans la Communauté Européene - NACE). Fontos kiemelni, hogy egyes, a gazdaságban legújabban megjelent ICT alapú tevékenységek esetében nagyon nehéz a NACE szerinti pontos besorolás.

\section{A tudásintenzív üzleti szolgáltatások innovációs jellemzői}

A szolgáltatások innovációjának tudományos vizsgálatát számos tényező nehezíti, többek közt az iparág heterogén jellege: jóllehet számos szolgáltatás esetében magas innovációs és technológiai aktivitás tapasztalható, elég nagy az a kör, ahol gyenge ez a tevékenység. A tudásintenzív üzleti szolgáltatások ugyanakkor innovációs szempontból tipikusan az aktív csoporthoz tartoznak. Azt is mondhatjuk, hogy a KIBS szolgáltatások a szolgáltatás innováció valódi bizonyítékai, amely aktuálissá teszi ez irányú vizsgálatukat. E tevékenységük a $\mathrm{K}+\mathrm{F}$ és az új fejlesztésủ kínálat arányának tekintetében ma sokkal inkább a termelő szektor jellegzetességeit mutatja. 
A statisztikák elemzéséből jól látható az is, hogy erős pozitív korreláció van a KIBS szektor foglalkoztatottsági aránya és az egy före jutó GDP között, azaz az ilyesfajta szolgáltatásokban dolgozók magas aránya a fejlettebb gazdaságokra jellemző (Uppenberg-Strauss 2010). Az is kivehetö, hogy az egyes országokban a KIBS szolgáltatások különbözőképpen járulnak hozzá a termelékenység növekedéséhez, s ugyanúgy erős korrelációt mutatnak a teljes innovációs mutatószámokkal.

A tudásintenzív üzleti szolgáltatások növekvő kvantitatív és kvalitatív szerepe tehát mutatja, hogy jelentős hányadban járulnak hozzá a teljes szolgáltatási szektor innovációs teljesítményéhez, amivel indokoltnak mondhatjuk a kiemelt tudományos vizsgálatukat. A fejlett gazdaságokban a KIBS szolgáltatások kutatása a tudásgazdaság és az innováció vonatkozásában történik, a korábbi elméleti irányok kombinációjának figyelembe vétele mellett, ami így széleskörűen járul hozzá a szolgáltatás innováció általános tudományos vizsgálatához is. Az innováció folyamatának tágabb értelmezése megfelelő keretrendszert adhat a KIBS innovációjának többdimenziós empirikus kutatásához. Így például

- az értéklánc és az üzleti hálózatok innovációs jellemzőinek vizsgálatával, amely a résztvevők közötti kölcsönös kapcsolatok és a szabályozó környezet hangsúlyosságát emeli ki;

- az ügyfél interakciókban, az ügyfélkapcsolat módjában és eszközeiben történt változások megfigyelésével és kiértékelésével;

- az új szolgáltatási rendszerek beazonosításával;

- az üzleti struktúrát, a vezetést és a munkamódszereket érintő szervezeti változások leírásával;

- vagy maguknak az innovációs modelleknek a feltárásával.

Természetesen ezen kutatások megalapozásában nagy segítséget jelent az elméleti fejlődés. A KIBS szolgáltatások ezen többdimenziós empirikus kutatási irányai közvetlen hatással lehetnek a szolgáltatás innováció alapjainak vizsgálatára, amelyen keresztül hozzájárulhatnak a hatékony innovációs politika alakításához, illetve bővíthetik a nemtechnológiai innovációs módszerek és eszközök körét. Az innováció nem-technológiai (vagy szervezeti) vonatkozása a szolgáltatási koncepciót, az ügyfélkapcsolatot (interface) és a szolgáltatásnyújtás rendszerét foglalja magában. A teljes technológiai szemlélettől történő elszakadás jelentős új eleme volt a szolgáltatás innováció kutatásának, ami a KIBS kutatásokat is közelebb vitte a stabil lehatároláshoz.

A KIBS vállalkozások innovációs tevékenységük során tipikusan a szakmai szervezeteket és hálózatokat, valamint gyakorlati tevékenységükben az ügyfelek konkrét igényeinek kiszolgálása során kidolgozott megoldásokat használják innovációs forrásként, melyben a szervezeti újítások viszonylag fontos szerepet játszanak. Így nem meglepö, hogy a szegmensben gyakori a beszállítói indíttatású innováció. A KIBS szolgáltatók ügyfelei, valamint az alkalmazotti kör ugyancsak lényeges forrásai az innovációnak, következésképpen szoros együttműködésük figyelhető meg a KIBS vállalkozásokkal, az új szolgáltatások kifejlesztésének teljes folyamata alatt. A téma kutatóinak ezért kiemelt feladata, hogy modellfejlesztéseikbe bevonják a releváns technológiai, közgazdaságtani és menedzsment eredményeket is, ami valójában interdiszciplináris megközelítést igényel. Ezért is fontosak a szintetizáló törekvések az elméletalkotásban.

Ahhoz, hogy vizsgálni tudjuk a KIBS vállalkozásoknak az innovációs folyamatokban betöltött szerepét, figyelembe kell vennünk, miként vesznek részt a tudás előállításában és 
felhasználásában. Emlékezzünk arra is, hogy az üzleti szolgáltatások előállítása a szolgáltató és az ügyfél közös erőfeszítéseként értelmezhetö. Ezért az effajta közös elöállításban a szolgáltatási eredmény minősége nagyban függ a résztvevő felek interakciójától, illetve a folyamatot érintő kommunikáció hatékonyságától. A KIBS szolgáltatók egyik leglényegesebb feladata a gazdaságban elérhető általános tudományos, technológiai, valamint üzleti ismeretek és információk lebontása és alkalmazhatóvá tétele az egyedi ügyfélproblémák megoldásához. Ezért a KIBS vállalkozások katalizátorként müködnek az üzleti területük általános tudásának és a vállalkozások gyakorlati működése során felhalmozott tacit tudásnak a kölcsönös egybeolvasztásában (interaktív tanulás). ${ }^{2}$ Míg az ügyfél szervezetek alapvetően kibővítik saját maguk korábbi tudásbázisát, addig a KIBS szolgáltatók leginkább a megszerzett új tapasztalatokkal és iparág-specifikus ismeretekkel gazdagodnak. A KIBS szolgáltatások innovációjának egyfajta alapja ezáltal a letisztultabb és differenciáltabb szolgáltatás, az új módszertan és a teljesen új piaci rés lehet. Ezen tevékenységük eredményeként az ügyfélvisszajelzések jelentős mértékben befolyásolhatják e szolgáltatások innovációit, de ugyanígy a vállalkozások is hatással lehetnek az ügyfeleik innovációira.

Fontos kiemelni tehát, hogy a tudásintenzív üzleti szolgáltatások nem csak aktív innovátorai a szolgáltató szektornak, hanem a tudástranszferben betöltött szerepük miatt fontos katalizátorai is az innovációnak - akár más iparágakban is. A KIBS szolgáltatók katalizátorként három módon járulhatnak hozzá más vállalkozások innovációjához.

- Segithetik az ügyfél eredeti, nem a KIBS vagy más vállalkozástól eredő innovációját. Lehetnek az innováció közvetitooii, amennyiben az eredetileg egy másik szervezetben (vagy iparágban) keletkezett.Lehetnek az innováció forrásai is, amennyiben saját maguk a kezdeményezői vagy kifejlesztői az adott innovációnak.

A fentiekben vázolt interakción alapuló innovációs mintákon túl a KIBS szektorban az információs és kommunikációs technológia adaptív alkalmazására épülő innovációt érdemes még megvizsgálni. A tudásintenzív üzleti szolgáltatások és az ICT kapcsolata kiemelt helyet foglal el a kutatásokban. A legdinamikusabban fejlődő szolgáltatások körében az ICT beruházások lényegesen magasabbak, mint más ágazatokban (azaz a termelő szektorhoz viszonyítva is). Mindez hatással van a KIBS szolgáltatások előállítási idejére és leszállítására is: az új technológiai megoldások megkönnyítik a megrendelést és a teljesítést, $\mathrm{s}$ a szolgáltatások elöállításának és fogyasztásának korábban általánosan elfogadott elválaszthatatlan jellemzőjét akár el is törlik. Ez jelentős mértékben megnöveli a KIBS szolgáltatások földrajzi elérhetőségét, illetve erősíti a nemzetközi verseny mértéket a korábban tipikusan lokális piacokon. Az elválaszthatóság további eredménye lehet a specializálódás újabb formája, amikor egyes KIBS vállalkozások a szolgáltatások elóállítási, míg mások a fogyasztási szakaszára szakosodnak.

A tudásintenzív üzleti szolgáltatások innovációs aktivitásának következő fontos ismérve a munkaintenzív jellegükből fakad, hiszen a KIBS vállalkozások jellemzően magasan képzett munkaerőt alkalmaznak, amely így kulcsfontosságú a számukra. Érdekes módon az ICT terjedése és beépülése e vállalkozások gazdálkodásába nem csökkenti, hanem éppen növeli az emberi erőforrásokba történő beruházások összegét. Ennek magyarázata az, hogy a komplex technológiai alkalmazások növekedése egyre magasabban képzett munkaerőt

2 Tipikusan ilyen KIBS vállalkozások a tanácsadó szervezetek (IT, menedzsment, müszaki). 
kíván, amely alkalmazni képes az ICT eszközeit a hatalmas mennyiségü információ tudássá történő alakításában. A KIBS szektorban jellemző tudás-kodifikációnak és az ICT beépülésének köszönhetően a tudás tacit összetevőinek fontos szerep jut abban a folyamatban, amely az információ, magas hozzáadott értékű szolgáltatásokká történő átalakításában ragadható meg. Mindez tovább növeli az emberi tudás hozzájárulását a KIBS szolgáltatások innovációjához.

Az ügyfelekkel szoros interakció egyik következménye, hogy a KIBS szolgáltatók más vállalkozásokhoz viszonyítva lényegesen több információval rendelkeznek a piac aktuális helyzetéről, az esetleges vevői problémákról, vagy éppen az üzleti lehetőségekről, ami csökkenti az innováció kockázatát és motivációt jelent a nemzetközi piacra lépéshez. Ugyanígy, azügyfél-szolgáltató együttműködésnekköszönhető erőforrás-és tudásmegosztás rugalmasabb alkalmazkodást tesz lehetővé, ami a tudásalapú szektorokban kifejezetten fontos szerepet játszik a fejlesztési kockázatok mérséklésében, s gyorsítja az innovációs folyamatokat (Fritsch-Franke 2004). Figyelembe véve, hogy a KIBS vállalkozások piacát a gyors technológiai fejlődés, a növekvő fejlesztési költségek és a szolgáltatások rövidülő életgöbéje jellemzi, a nemzetköziesedés menekülő utat jelenthet számukra. Az információs technológia használata esetükben nem csak a termelékenységet, de a nemzetköziesedést is gyorsítja. ${ }^{3}$ Másrészről a nemzetközi piacra lépéssel sokkal szélesebb tudásanyaghoz férnek hozzá, ami visszahatóan ad stratégiai lehetőséget az innovációs készségek és kapacitások fejlesztésére is. A piaci verseny intenzív kihívásai és a dinamikus technológiai változások ezért nemzetközi szinten felértékelik az innovációt mint gazdálkodási eszközt.

A fentiekben bemutatott kutatási eredményekből is láthatjuk, hogy a KIBS innovációkban (a termelő vállalkozásokhoz hasonlóan) a legfontosabb meghatározó tényező a formalizált tudás. A tudás formalizálásának belső igénye pedig jelenleg leginkább a nagyvállalatokra jellemző, ami felveti a vállalati méret innovációs szerepének kérdését. A termelő szektorban pozitív korreláció figyelhető meg az innovációs tevékenység és a szervezeti méret közt, míg ugyanez nem mondható el a tudásintenzív üzleti szolgáltatásokról, hiszen a jelenleg megfigyelt kapcsolat tevékenységi területenként eltérő. Emellett az már jól látható, hogy a külső (a szervezeten kívülről származó) innováció leginkább a folyamat-innovációs tevékenységekre, míg a belső (a KIBS szervezeteken belüli) innováció magának a kínált szolgáltatásnak az innovációjára jellemző. Ugyanakkor a KIBS vállalkozások abszorpciós kapacitása, vagyis a tudásállomány külső ismeretforrásokon (például alapkutatási eredményeken, vagy külföldi technológiákon) keresztüli növelésének képessége, leginkább a termékfejlesztési innovációban játszik érdemi szerepet (Musolesi-Huiban 2010).

\section{Összegzés}

Jelenleg az egyes szolgáltatási tevékenységek nem egyforma mértékben kapcsolódnak az innovációs rendszerekhez, jóllehet itt hiányoznak az ösztönzéshez szükséges intézményi és egyéb formális támogató szisztémák. Utóbbiak pedig nem csak tudásközpontokként

\footnotetext{
${ }^{3}$ Az elmúlt évtizedekben a szolgáltatások nemzetközi kereskedelme nagyobb ütemben növekedett, mint az árucikkeké (Szalavetz 2008). Ez ellentétes a korábbi tudományos felfogással, hiszen, a kutatók hagyományosan úgy tekintettek a szolgáltatásokra, mint amelyekkel nem lehetséges kereskedni. A szolgáltatásokra ma ugyanúgy jellemző a globalizáció, mint a fizikai termékekre.
} 
szolgálhatnának a vállalkozások számára, de hozzájárulhatnának az innovációk védelméhez és terjedéséhez is. Az, hogy szolgáltatások körében (a termelő szektorral ellentétben) hiányzik a szellemi tulajdon hatékony védelme, nagy kockázatot jelent, ami gátolja az optimális tudástranszfert a gazdaságban, s pazarló, duplikált innovációs erőfeszítésekhez vezet. Mindemellett a nagy szolgáltató vállalatoknak is aktív szerepük van a szolgáltatás innováció előmozdításában, különösen a tudásintenzív üzleti szolgáltatások körében.

A KIBS vállalkozások (föként kis- és középvállalkozói szinten) tulajdonképpen nem is tudják milyen irányba indulhatnak, ha tudatosan innovációs tevékenységet szeretnének folytatni, ezért a szektorban - az elméleti eredmények mellett - nagy az igény a konkrét üzleti módszertani alkalmazások kifejlesztésére is. A piacon szabadon elérhetö, hatékony, kifejezetten a KIBS szolgáltatásokra kifejlesztett kutatás-fejlesztési módszerekkel vélhetően kimagasló hatékonyságnövekedés lenne elérhető a gazdaságban.

A KIBS szolgáltatások innovációs folyamataihoz igénybe vehető $\mathrm{K}+\mathrm{F}$ szolgáltatásokkal a vállalkozások gyors fejlődésnek indulhatnának. Ennek kezdeti lépéseként javasolt lenne bátorítani a tudás- és tapasztalat-megosztást, valamint az innovációs folyamatok problémáinak közös feldolgozását a szektorban, jóllehet ezt nagyban nehezíti a szellemi tulajdon jelenleg problémás védelme. Természetesen figyelemmel kell lenni az alkalmazottak és az ügyfelek visszajelzéseire, de ami ennél sokkal nehezebb feladat: meg kell próbálni a kifejezett igények és problémák, valamint a piaci trendek mögé látni. A specifikus kutatásfejlesztési módszerek és technikák ebben nagy segítségre lehetnének. Az innovációt és az innovációs szemléletet a KIBS vállalkozások mindennapi működésének részévé kell tenni: egyfajta életformaként kell azt elsajátítaniuk, s nem elérhetetlen akadémiai tevékenységként kezelniük.

Fontos még megemlítenem, hogy a szolgáltatás innováció a termék innovációval szemben lényegesen kevesebb figyelmet kap az egyes nemzetgazdaságokban az állami ösztönzők körében is, jóllehet, mint azt fentebb is említettem, a szolgáltatások jelentős hányadban járulnak hozzá az országok gazdasági növekedéshez. Ennek a figyelemhiánynak több oka is van, de talán a célzott intézményi felzárkózás elmaradása emelhető ki leginkább. Ha e téren sikerülne elörelépni, az kiváló kezdete lehetne a szolgáltatás innováció hatékonyabb ösztönzésének. Nemzetgazdasági szinten ugyanis a releváns innovációs rendszerekhez történő kapcsolódások hozzáadott értéke jelentősen meghaladja az ezzel járó fejlesztési befektetések költségét, az innovációs kapacitás bővülése pedig egyértelmüen gyorsabb és stabilabb gazdasági növekedést eredményez. Fokozottan érvényes ez a tudásintenzív üzleti szolgáltatások esetében. Érdemes tehát további kutatásokkal feltérképezni, mennyire lehetnek hatékonyak az ezen iparág innovációs potenciáljának növelését támogató központi ösztönzők.

\section{Hivatkozások}

Barras, R. (1986): Towards a theory of innovation in services. Research policy, Vol. 15, No. 4:161-173.

Bettencourt, L. A. - Ostrom, A. L. - Brown, S. W. - Roundtree, R. I. (2002): Client co-production in knowledge-intensive business services. California Management Review, Vol. 44, No. 4:100-128.

Fritsch, M. - Franke, G. (2004): Innovation, regional knowledge spillovers and R\&D cooperation. Research Policy, Vol. 33, No. 2:245-255.

Gallouj, F. - Savona, M. (2009): Innovation in services: a review of the debate and a research agenda. Journal of evolutionary economics, Vol. 19, No. 2:149-172.

Den Hertog, P. - Broersma, L. - Van Ark, B. (2003): On the soft side of innovation: services innovation and its policy implications. De Economist, Vol. 151, No. 4:433-452. 
Den Hertog, P. (2000): Knowledge-intensive business services as co-producers of innovation. International Journal of Innovation Management, Vol. 4, No. 4:491-528.

Lööf, H. - Heshmati, A. (2006): On the relationship between innovation and performance: a sensitivity analysis. Economics of Innovation and New Technology, Vol. 15, No. 4-5:317-344.

Miles, I. - Kastrinos, N. - Flanagan, K. - Bilderbeek, R. - Den Hertog, P. - Huntink, W. - Bouman, M. (1995): Knowledge-intensive business services. Users, Carriers and Sources of Innovation. European Innovation Monitoring System Reports.

Miles, I. (2005): Knowledge Intensive Business Services: Prospects and policies. Foresight, Vol. 7, No. 6:39-63.

Mosoniné Fried Judit - Tolnai Márton - Orisek Andrea (2004): Kutatás-fejlesztés és innováció a szolgáltatási szektorban. Nemzeti Kutatási és Technológiai Hivatal, Budapest.

Musolesi, A. - Huiban, J. P. (2010): Innovation and productivity in knowledge intensive business services. Journal of Productivity Analysis, Vol. 34, No. 1:63-81.

Pavitt, K. - Robson, M. - Townsend, J. (1989): Technological accumulation, diversification and organisation in UK companies, 1945-1983. Management Science, Vol. 35, No. 1:81-99.

Szabó Katalin (2002): Az információs technológiák szétterjedésének következményei a hagyományos szektorokban. Közgazdasági Szemle, Vol. 49, No. 3:193-211.

Szalavetz Andrea (2008): A szolgáltatási szektor és a gazdasági fejlödés. Közgazdasági Szemle, Vol. 55, No. 6:503-521.

Toivonen, M. (2006): Future prospects of knowledge-intensive business services (KIBS) and implications to regional economies. ICFAI Journal of Knowledge Management, Vol. 4, No. 3.

Uppenberg, K. - Strauss, H. (2010): Innovation and productivity growth in the EU services sector. European Investment Bank, Luxembourg. 